\title{
Expressionsstabilität in transgenen Erbsen - Heterologe Expression von Polygalakturonase-inhibierenden Proteinen in transgenen Erbsen
}

\author{
A. Richter, M. Müller, H. Kiesecker, H.-J. Jacobsen \\ Lehrgebiet Molekulargenetik, Universität Hannover \\ Korrespondenz an: Andrea Richter, Lehrgebiet Molekulargenetik, Universität Hannover, Herrenhäuser Str. 2, 30419 Hannover, \\ E-mail: Richter@Igm.uni-hannover.de \\ Eingegangen: 5. September
}

Die Erbse (Pisum sativum L.) dient der menschlichen und tierischen Ernährung und wird hauptsächlich in gemäßigten Regionen angebaut. Der sehr begrenzte Genpool der Erbse erschwert die Züchtung, die insbesondere auf eine Erhöhung der Krankheitsresistenz gegenüber phytopathogenen Pilzen ausgerichtet ist. Am Lehrgebiet Molekulargenetik der Universität Hannover wird ein gentechnischer Ansatz zur Resistenzverbesserung der Erbse verfolgt und mit klassischer Züchtung kombiniert. Hierbei wurden transgene Erbsenpflanzen, die verschiedene antifungale Gene integriert hatten, auf molekularer Ebene charakterisiert und zur Kreuzung verwendet. Zur Agrobakterien-vermittelten Transformation waren folgende antifungale Gene verwendet worden: zwei Gene, diefür Polygalakturonase-inhibierende Proteine aus Kiwi (Actinidia deliciosa L.) und Himbeere (Rubus idaeus L.) kodieren und das vst1-Gene aus der Weinrebe (Vitis vinifera L.), welches für Stilbensynthase kodiert. Das bar Gen wurde als Selektionsmarker verwendet.
Im Rahmen der Charakterisierungsarbeiten zeigten sich verschiedene Silencingmechanismen des bar Gens.

Der Effekt des heterolog exprimierten Polygalakturonaseinhibierenden Proteins aus der Himbeere auf verschiedene pilzliche Polygalakturonasen wurde mittels Agarosediffusionstest überprüft und quantifiziert.

Die Analyse der Mutterlinie (98-19-1,9) und einer Kombinationslinie (02/484) zeigten starke Expressionsunterschiede zwischen Individualpflanzen einer Linie sowie innerhalb der Pflanze. In Organen wie Blüten, Hülsen und Apex konnte eine besonders starke Expression festgestellt werden. Zudem hatte das Alter der Pflanzen einen großen Einfluss auf die Expressionsstärke des PGIPs.

Resistenztests sollen zeigen, inwieweit sich diese Expressionsinstabilität des Transgens auf das Resistenzverhalten der Pflanzen auswirkt. 